\title{
Implementation of the Islamic Quality Management System MS1900 and its Benefits: A Case Study at the Department of Hajj, Waqf and Zakah, Malaysia
}

\author{
Hasliza Mohamad Ali (Corresponding Author) \\ Department of Siasah Syar'iyyah, Academy of Islamic Studies, University of Malaya (UM), \\ 50603, Kuala Lumpur, Malaysia \\ Tel:+601387841 E-mail: haslizama@gmail.com \\ Siti Arni Basir \\ Department of Siasah Syar'iyyah, Academy of Islamic Studies, University of Malaya (UM), \\ 50603, Kuala Lumpur, Malaysia \\ Tel:+60172847779 E-mail: sitiarni@um.edu.my \\ Musaiyadah Ahmadun \\ Department of Siasah Syar'iyyah, Academy of Islamic Studies, University of Malaya (UM), \\ 50603, Kuala Lumpur, Malaysia \\ Tel: +60192061561 E-mail: musaiyadah@siswa.um.edu.my
}

\begin{abstract}
:
The MS 1900 is an Islamic Quality Management System (QMS) which was launched by the Government of Malaysia in 2005. It is a structured system to assist organisations to deliver products and services that meet customer's requirements, as well as the regulatory requirements and dictates of the Shari'ah (Islamic commandments). The Shari'ah requirements are additional to the requirements of ISO 9001, and aim to close the gap between the ISO 9001 standard and the Islamic perspective. MS 1900 has attracted considerable attention from Malaysian organizations but only a number of empirical studies have analysed the process of its implementation. Additionally, organisations that have successfully obtained QMS certification are still plagued with problems. Therefore, there is a need to study how MS 1900 is being implemented in certified organisations. The objective of this study is to examine activities conducted within the MS 1900 implementation process at the Department of Hajj (Muslim pilgrimage), Waqf and Zakah (DHWZ) in Malaysia and explore the benefits accrued from its implementation. A qualitative approach and case study strategy were used to
\end{abstract}

investigate MS 1900's implementation at the DHWZ. Semi-structured interviews were employed as the main data collection method to obtain in-depth information on the subject. Interviews were then triangulated with information from documents. The study found six main activities that were undertaken in MS 1900 implementation at the DHWZ, namely gap analysis, preparing the documentation, creating quality groups, implementing work procedures, as well as internal and external audits. The study also identified three benefits accrued from MS 1900 implementation; these are achieving the client's charter, the listing of being an outstanding religious department, and systematic job management. The MS 1900 implementation has also helped managers implement strategic planning at the DHWZ. This study adds to knowledge of the emergence and development of the Islamic QMS MS 1900 and contributes particular insights into its implementation within Malaysian Islamic institutions. Findings from this paper could be used by managers in government or private institutions as a guideline in their endeavours to implement the MS 1900 effectively.

Keywords: Islamic Quality Management 
System MS1900; Malaysia; Implementation; Benefits; Department of Hajj (Muslim Pilgrimage); Waqf And Zakah (DHWZ)

\section{Introduction}

Islam is considered the fastest growing religion in the world (Saeed et al., 2001) and the world's Muslim population is expected to increase by 35 per cent in the next 20 years, from 1.6 billion in 2010 to 2.2 billion by 2030 (Pew Research Centre, 2013). Islam is a progressive religion that is applicable in all aspects of life (Hassi, 2012) and researchers see the establishment of the Islamic Quality Management System MS1900 as being timely.

Historical records show that knowledge in quality management came from the United States of America over 80 years ago, as it had its own specialists in Dr Walter Andrew Shewhart and Dr William Edward Deming. The arrival of Deming in Japan in 1974, two years after the Second World War, opened a new chapter in quality management knowledge. Deming was invited by the Japanese Union of Scientists and Engineers (JUSE) to share his expertise in the area of quality control (Abdullah, 1996) as he had previously joined the U.S. Census Bureau in 1939. The Japanese needed guidance from Deming because they had aspirations to become a developed nation like the United States. Based on their efforts, Japan emerged shortly thereafter as producer of electronic devices and automobiles in the world (Richard, 1995).

The Malaysian Department of Standards is a member of the International Organization for Standardization (ISO) and the International Electro-Technical Commission (IEC). This membership status is relevant because ISO Council members are entitled to participate in the formulation of international standards related to trading activity and to protect the Malaysian interests in the field of standards (SIRIM, 2013). The Malaysian Department of Standards, therefore, in collaboration with SIRIM and the Malaysian Institute of Islamic
Understanding (MIIU), reviewed the suitability of ISO 1900 from an Islamic perspective to modify requirements of the ISO 9001 that did not conform to Islamic regulations (Sany et al., 2011). The requirements of ISO 9001 had been integrated with Shari'ah elements, which consequently produced the Islamic Quality Management System MS 1900 (Certified Website, 2014). The MS 1900, launched by the Government of Malaysia in 2005, is a structured system to assist organizations to deliver products and services that meet customer's requirements, as well as regulatory requirements and the dictates of the Shari'ah (Islamic commandment). The Shari'ah requirements are included as additional to the requirements of ISO 9001, and aim to close the gap that exists in the ISO 9001 standard in relation to the Islamic perspective (Basir \& Azmi, 2013).

The MS 1900 has attracted considerable attention from Malaysian organizations and it appears that interest to implement the MS 1900 is significant. A total of 27 organizations have thus far been successfully awarded MS 1900 certification (Malaysia Certified, 2014). Despite the interest in MS 1900 QMS, there are only a number of empirical studies to examine the process of implementation of the MS 1900. Only two previous empirical studies by Basir et al. (2013) and Hassan (2015) relate to MS 1900 implementation. Additionally, organisations that have successfully obtained QMS certification are still plagued with problems such as negative attitudes, excessive workloads, and lack of training, monitoring and funding (Hassan et al., 2015). Therefore, there is a need to study how MS 1900 is implemented in certified organisations. This study aimed to investigate activities undertaken to implement the MS 1900 in Islamic institutions in Malaysia and examine the benefits obtained from its implementation. The Department of Hajj (Muslim Pilgrimage), Waqf and Zakah was chosen because it was the first government department in Malaysia that was certified by MS 1900 and had yet to be studied. 


\section{Background on the Islamic Quality Management System MS 1900}

The MS 1900 integrates Islamic values into ISO 9001. Although it was established based on the framework of ISO 9001, MS 1900 is unique for having Islamic terms such as Shar'iah Compliance, Fiqh Council, Shari'ah Advisory Committee, Shari'ah Compliance Unit, Halal, Quran, Hadith, Sunnah, Al-Ijma' and Fatwa (Technical Committee, 2005).

The first objective of the MS 1900 is to develop and integrate Shari' ah requirements into quality management practices and to emphasize valuebased management. The second objective is to enhance the effectiveness and efficiency through good ethical practices (i.e. universallyaccepted good conduct) at all levels of the organization. The third objective is to increase the level of compliance and confidence with Shari'ah requirements among Muslims and stakeholders. Syed Azauddin (2005) stated that many non-Muslims relate the term standard Islamic management with the term 'halal'. Thus, the word 'halal' is widely used in various fields, including in the business world. Businessmen who want to penetrate the Muslim market need to put the 'halal' label on their products. However, there have been times when labelling was obtained illegally and without approval of the authorities. These problems can affect the confidence of customers and stakeholders.

\section{Principles of the Islamic Quality Management System MS 1900}

The MS 1900 has three basic principles which are (i) compliance with the principles of halal and haram; (ii) value-based operations; and (iii) that actions taken and decisions made should be referred to the Maqasid Shari'ah.

\section{Compliance with the Principles of Halal and Haram}

The main basis in Islamic law is that Allah (s.w.t) created all things as halal and permissible
(Yusuf, 2004), but becomes illegal when they are in contrast with proofs of the clear texts of the Qur'an and Sunnah. Each item that is haram or illegal or anything that is related to haram or illegal things is considered as haram or illegal from the Islamic perspective. If the dangers outweigh the benefits, it is haram (i.e. illegal), and if the benefits outweigh the dangers, it is halal. In Islam, the routines of life and worldly affairs can be transformed into worship and obedience to Allah if they are accompanied by good intentions. Consequently, action that is carried out by Muslims and accompanied by good faith is considered an article of faith. On the other hand, an item that is illegal remains illegal no matter how good the intentions are, how noble the purpose is or how high the goal is. Islam provides a guide that if things are dangerous, they are haram (i.e. illegal). Items that are not fit to be judged are disapproved (i.e. makruh) and the things that bring benefits are encouraged (i.e. sunat) (Yusof, 2004).

\section{Value-based Operations}

Islam is a universal religion that offers many noble values. Islamic values have relevant and dynamic properties, consistent with human needs for organizing and progressing organizations. Good values should be included in organizational development. Islam has established guidelines on values that must be adopted by an administrator or an employee to ensure that core ethics form the affairs of the services they provide and are judged by Allah SWT (Yusuf, 1993). Mohd Affandi Hassan (1992) added that the concept of management and administration in Islam should fulfil the original contract between Allah and man, where man is as a servant and the vicegerent of Allah on this earth. This kind of management ensures the elimination of corruption, damage, and injustice to establish equality and order in organizations and communities. The attributes that are important in the conduct of organizational operations are based on the value of trust, sincerity, discipline and dedication. 


\section{Decisions and Actions Taken Should be Referred to Maqasid Shari'ah}

Wahbah Al-Zuhaily (2006) defined Maqasid Shari'ah as an objective of Islamic law to preserve nature and keep people from engaging in destructive activities or actions. Therefore, the goal of Maqasid Shari'ah is for human interest and to avoid any harm. In this regard, Muhammad Abu Zahrah (2009) outlined three key aspects in the Maqasid Shari'ah, which are to educate individuals, uphold justice in the community of Islam and to overrule damage.

Yusuf al-Qaradawi (2008) expressed that human interest are categorised into three categories in Islam, which is need (Daruriyyah), necessity (Hajiyyah) and completeness (Tahsiniyyat). Darruriyyah is something that is mandatory for human existence. There are five things in the category of Darurriyyah and they are religion, life, intellect, property and lineage. Meanwhile, Hajiyyat facilitates the implementation of Daruriyyat and includes providing premises to provide space for business activities contained in Daruriyyat, for example. It is a necessity and not a need, because if it was not developed in that area, business activities could still be done such as through social media, Facebook and through the classified advertisements in the print media. Finally, Tahsiniyyat is placed on the last level because its function is to preserve social ethics. The efforts of Tahsiniyyat are included in the Shari'ah, and include visiting the sick, reading the Quran, being thrifty while going shopping and not throwing garbage anywhere. Thus, the concept of Maqasid Shari'ah should be empowering and clearly understood by individual Muslims. Islam-centric decision making is guaranteed to give justice to all sides and lift humanity in places that matter the most.

\section{MS 1900 Implementation Activities}

Basir et al. (2013) disclosed 12 steps in the implementation of the MS 19000 in the Malacca Zakah Center. These are (i) to identify the gaps, (ii) to understand the MS 1900 quality management system, (iii) to establish a policy on quality,(iv) to established a working group, (v) to set up a management representative, (vi) to get top management commitment, (vii) to ensure documentation is completed, (viii) to determine the scope of the quality management system, (ix) to implement the quality management system, (x) to carry out an internal audit, (xi) to evaluate the performance of the quality management system , and (xii) to carry out an external audit for MS 19000 certification. Hassan (2015) identified activities in the MS 1900 implementation as (i) developing an understanding of MS 1900, (ii) establishment of a working committee, (iii) management review meetings, (iv) management commitments, (v) internal and external audit executions, (vi) corrective and preventive actions, (vii) continuous improvement, and (viii) adherence to Shari'ah requirements. Basir \& Azmi (2011) developed the model for MS 1900 implementation, and demonstrated a theoretical model that entailed three components, namely implementation steps for ISO 9001, Shari'ah requirements in MS 1900, and principles of MS 1900. They advocated that since the basis of MS 1900 was ISO 9001, organizations intending to obtain MS 1900 certification should implement the ISO 9001 first. The ISO 9001 implementation process involved 13 steps and should be integrated with Shari' ah elements that were embedded in the MS 1900 requirements. They also outlined five steps in the ISO 9001 implementation process that could be integrated with Shari'ah elements, namely understanding the quality system, preparing documentation, demonstrating commitment, clarifying policy on quality, and performance audit and review.

Principles of the MS 1900 should be employed as a foundation for the MS 1900 implementation process. There are three MS 1900 principles that are in compliance with the principles of 'Halal' and 'Haram', operating based on values and decisions taken in accordance with the 'Objectives of Shari'ah' or Maqasid Shari'ah (Basir \& Azmi, 2011). 


\section{MS 1900 PRINCIPLES}

- Compliant with the principles of Halal and Haram

- Organization operates based on values

- Decisions are taken in accordance with the 'Objectives of Shari'ah' or Maqasid Shari'ah

Implementation steps of the ISO 9001

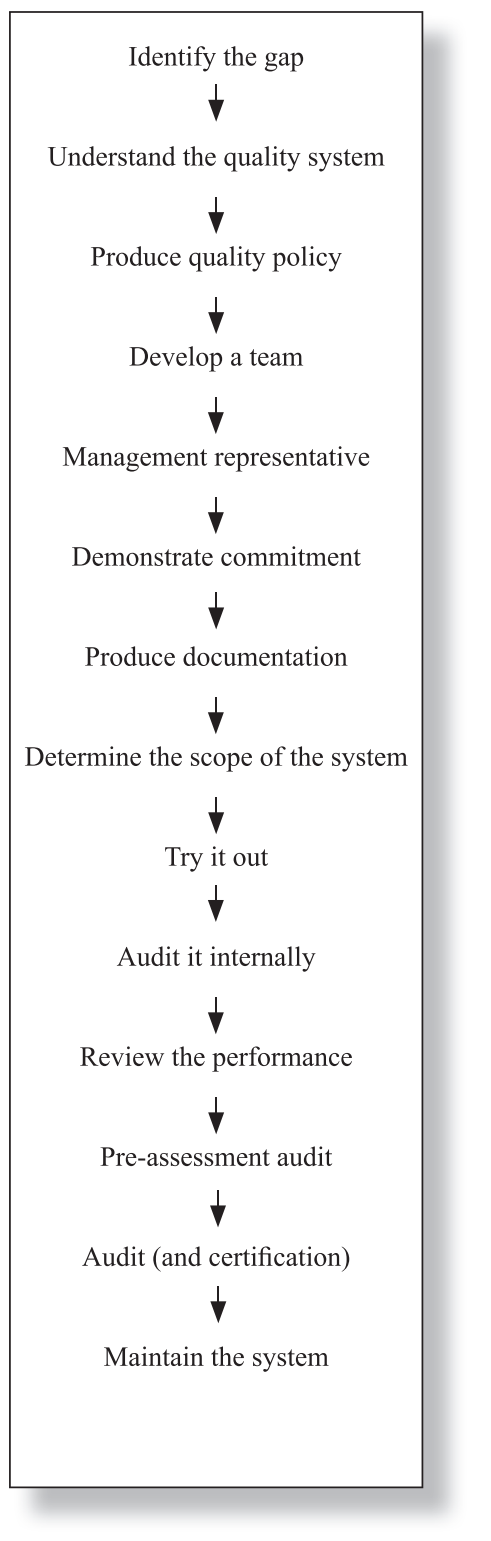

SHARI'AH ELEMENTS IN

MS 1900

REQUIREMENTS

Figure 1: Model of the Implementation Process of the Malaysian Quality Management System MS 1900 from an Islamic Perspective

Source: Basir \& Azmi (2011) 


\section{Benefits of the Implementation of the MS 1900}

Ilhaamie et al. (2013) argued that MS 1900 implementation brought benefits, such as becoming a guide for the preparation of halal products and services nourished with Islamic values; highlighting the human aspect; upholding stakeholders' interests; becoming the benchmark for quality management systems for products and services; continuous improvement, improving customer trust; increasing market share; enhancing transparency; protecting workforce interests; and organisational image enhancement. Meanwhile, Basir \& Azmi (2011) suggested that the implementation of the MS 1900 not only helped organisations improve their management systems, but also enabled organizations to practice management systems that complied with Shari'ah and Islamic obligations. Complying with Shari'ah obligations also led to many benefits for organisations, such as receiving Allah's blessings, market growth, increasing public trust, increasing the confidence of Muslim customers, enhancing Islamic quality culture, and improving organizational management as a whole.

From the case study that was conducted by Basir et al. (2013), it was revealed that the MS 1900 implementation at Malacca Zakah Center had many positive effects, including making work procedures clear and robust, meeting customer needs, developing quality in culture, promoting continuous improvement, as well as stimulating work excellence, teamwork and time management. Another case study carried out by Hassan (2015) at a private institution of higher education in Malaysia indicated that many benefits accrued from MS 1900 implementation and these included simplifying tasks and work procedures, improving practices based on Islamic values, promoting a friendly environment, enhancing the organisational image and becoming a reference organization. Other benefits were improving the academic program, encouraging a culture of work excellence, adherence to the Shari'ah commandment, and enhancing administrative and academic staff satisfaction.

\section{Methodology}

The authors initiated the study with the idea of thinking, that is about the problem to be studied as suggested by Awang (2009). The data were collected based on the case study strategy. Piaw (2011) stated that the design of a case study involved the systematic collection of information and understanding of individual behaviour, including social or special events to find out how individual behaviour or social change occurred. The Department of Hajj (Muslim Pilgrimage), Waqf and Zakah (DHWZ) is a government department under the auspices of the Prime Minister. Its inception was on 27 March 2004 (or 6 Safar 1425H) by YAB Dato' Seri Abdullah bin Ahmad Badawi while making the announcement of the cabinet of Malaysia at that time (DHWZ, 2007). On 8 October 2004, DHWZ was officially launched by the former Minister in the Prime Minister's Department, YB Dato' Dr. Md Abdullah Zin (DHWZ, 2007).

Awang (2009) stated that data could be categorised into quantitative and qualitative data. As an inductive enumerative approach was used and DHWZ was chosen as the case study, the appropriate data collection is qualitative. Richards (2006) described the method of qualitative data collection as involving three types of data collection, consisting of interviews, document reviews and observations. The semistructured interview method was chosen as the lates data collection method to gain in-depth and latest information on the implementation of MS 1900 in DHWZ. Interviews give people who are being interviewed the freedom when submitting responses. To ensure that the interview went well, interview questions were provided beforehand. The interviewees were selected based on their active involvement in MS 1900 implementation at DHWZ. A total of 15 interviewees were involved and they consisted of officers in top management and 
general officers at DHWZ. Apart from semistructured interviews, a document review was also being used as a data collection method. A thematic analysis suggested by Braun \& Clarke (2006) was used as a data analysis method in this study. By employing these data collection methods, the themes relating to MS 1900 implementation activities and the benefits accrued from them were identified and developed.

\section{Result and Discussion}

\section{MS 1900 Implementation Activities at DHWZ}

The certification of the MS 1900 at DHWZ has been in line with the department's goal of DHWZ 2020, which is to make the DHWZ a world-class government department. For three consecutive years (2011 until 2013), the annual report of the department has received courtesy calls from delegates from local and foreign agencies. This proves that the department took the initiative to have contact with outside networks and built a good reputation and image. Research findings from this study revealed six main activities that carried out at the department during the early stages of MS 1900 implementation. These activities were analysing the gap, preparing the documentation, creating quality groups, implementing quality procedures, as well as carrying out internal and external audits.

\section{Gap Analysis}

The implementation of a quality system began with a gap analysis to determine discrepancies between company procedures and the quality management system framework (Fuentes et al., 2000 and Bhuiyan \& Alam, 2005). The research findings from this study revealed that DHWZ had taken certain measures to analyse the gaps that existed during the early stages of the MS 1900 implementation. The department referred to the standards contained in the ISO 9001 (2008) as these were the same clauses as in MS 1900, the difference being that MS 1900 was supplemented with elements of the Shari' ah in each clause. Officials at the department had to keep details of every aspect of the implementation to ensure that it conformed to the requirements of Islamic law. Apart from that, the department had also organized workshops to identify the programs, activities and core areas that should be fully considered in the implementation of the MS 1900. Talks and discussions were held in the early phase with the aim of providing an understanding on the MS 1900 for the entire workforce at the department.

After conducting the gap analysis, the DHWZ management found that there was a difference between the existing management system and the requirements of the MS 1900. Therefore, all existing work activities and processes were modified to make them parallel to the MS 1900 requirements, such as in the selection of vendors, hotels, catering service providers and others. This was because there was the additional of a Shari'ah committee at the department who were more concerned about whether service providers to the department had halal certificates or not. Following the implementation of the MS1900, the DHWZ management became concerned about aspects of discipline, such as punctuality, dress appropriateness, not missing out on prayers, and practising the Islamic work ethics among employees. The research findings revealed that the department had analysed gaps between the existing management system and the MS 1900 quality management system before embarking on implementing it. These findings are, in fact, in line with Basir et al. (2013) and Hassan (2015) who found that analysing was the first step in the MS 1900 implementation. Bhuiyan \& Alam (2005) also suggested that gap analysis could be an exercise conducted by the organisation itself (self-assessment) or by an external organisation.

\section{Preparing the Documentation}

Documentation is required when the absence of procedures could adversely affect quality. The documentation will be organised into a quality manual or a procedure manual (Fuentes et al., 
2000; Seaver, 2001 and Bhuiyan \& Alam, 2005). The research findings from this study disclosed that MS 1900 at DHWZ involved documentation aspects of the quality management system. In the beginning, the department created and maintained the quality management system within the context of DHWZ itself to meet customer requirements. These documentation included quality manuals, quality procedures, and supporting documents or quality records.

\section{Quality manuals}

Quality manual was a document used by the department to describe the scope, policy and planning of DHWZ and acted as the main reference for the quality management system to be implemented and maintained in accordance with the requirements of the MS1900. Among its contents are sections on introduction, information on the organization, its mission and vision, organizational structure, its charter, the quality management systems, scope of the implementation and relevant flowcharts. Being under the auspices of the Prime Minister's Department, the DHWZ sets objectives and quality in line with the mission and vision at the national level. Therefore, the department should be proactive and focused, and have a strategic plan in line with national aspirations. The emphasis on the quality of human capital is aggravated as it is a contributing factor and will have an impact on the success of the department. In the event of any detection of weaknesses, improvements should be made by enhancing corporate governance to make the department an excellent organization in terms of its management.

\section{Quality procedures}

Quality procedure was a document the department outlined for the purpose of identifying work steps and their sequences, and details the work processes for an activity in terms of how, why, when, where and who is performing it. These quality procedures form the basis of the MS 1900, which were divided into two categories - specific and supporting quality procedures.

Specific quality procedures were also provided for the core parts of DHWZ, which are the waqf, zakah and hajj (Muslim pilgrimage) and they are influenced by the rules and laws of the government. Each core part had to choose one critical activity that represented the total activities contained in the quality management system, MS 1900. This situation was not addressed in supportive quality procedures as the purpose of this manual was to support the core activities of management and administration and was used in conjunction with the specific quality procedures for each core activity.

\section{Supporting document or quality record}

A supporting document or quality record was produced by the department as a document for guidance and was to be followed when carrying out the work activities that had been documented. Supporting documents included the Malaysia Plan Book, National Land Code, State Islamic Religious Enactment, Treasury Instruction, Government Circulars and Treasury Circulars. These were usually used to determine the specific and supporting documents, and if DHWZ found that there were amendments, they had to complete the amendment documents. The department also had to provide justification to the Deputy Director-General and DirectorGeneral for procedures to be revised.

The research findings indicated that all parties at DHWZ had taken the necessary steps in the documentation processes that were needed for MS 1900 implementation. The documentation processes involved main documents such as quality manuals, quality procedures and quality records. These results strengthened the findings by Basir et al. (2013) that documentation was a necessary step in MS 1900 implementation. Basir \& Azmi (2011) also suggested that the documentation process in MS 1900 implementation had to be complied with according to the Shari'ah requirements. 


\section{Establishing a Quality Group}

A committee needed to be established that consisted of cross-functional members and that was made up of key personnel. The function of the committee was to discuss the system implementation, to set a timeframe, to provide resources and to discuss audit results (Fuentes et al., 2000; Seaver, 2001 and Bhuiyan \& Alam, 2005). The research findings from this study revealed that the workforce who was directly involved in the MS 1900 certification were officers who produced DHWZ's documents and acted as the quality group at the department. For the success of the quality agenda at DHWZ, it needed the participation of the entire workforce at the department. Staff at the Division of Research and Coordination became the secretariat that handled the quality manual, as they were responsible for the MS 1900 certification, with support from the top management.

The quality group was established to ensure that the implementation of the programme complied with the prescribed work procedures and to facilitate activities in line with the MS 1900 implementation. This quality group also offered suitable advice to the officers with regards to the MS 1900 implementation and measures to prevent cases involving Non-Compliant Reports (NCR).

The research findings disclosed that a quality group was established at DHWZ and ensured that MS 1900 was implemented effectively. These findings corresponded with Hassan (2015) who disclosed that top management in MS 1900 certified organisations had established a quality group in their endeavour to implement MS 1900 effectively. These findings also agreed with the suggestion from Basir \& Azmi (2011) that establishing quality teams was one of the steps to be taken in the process of the implementation of the MS 1900.

\section{Implementing Work Procedures}

This study also revealed that the management at DWHZ ensured the success of the implementation of MS 1900 by guaranteeing that all activities complied with work procedures. The management had to ensure that the quality objectives were met and that transactions were conducted to comply with the standards prescribed by MS 1900. The MS 1900 was also to be updated from time to time to remain relevant to the needs of DHWZ and inconsistent quality procedures were to be replaced if necessary.

The issues of authority limits, audit results, and continuous improvements were discussed at the Management Review Meetings (MRM). These were discussed to find a solution to ensure that the problem will not affect the implementation of MS 1900 and the daily activities at DHWZ. These results actually strengthened the findings by Seaver (2001) who found that the quality system had to be reviewed to ascertain if it was delivering the benefits expected by the organisation. They were also in line with Hassan (2015) who pointed out that complying with work procedures was one of the activities needed for MS 1900 implementation to be delivered smoothly.

\section{Internal Audits}

The research showed that DHWZ had not had a specific internal audit unit because it had been removed and transferred to the Prime Minister's Department from 2008 (DHWZ, 2008). The department was then creating the Internal Audit Management Committee under the MS 1900 and this committee would be assigned the task of performing the audit according to the implementation of MS 1900, which was to be carried out twice a year. Internal audits were carried out to focus on work procedures and examined if they were being complied with. Prior to the audit, the auditor submitted a form and specified that he would be carrying out the audit. It provided the DHWZ workforce the time 
and opportunity to check their documents before the day of the audit. During the audit, all officers entrusted with providing quality documents would be directly involved. The internal audits were divided into groups, and each group had a chief auditor. These findings concurred with that of Motwani et al. (1996), Seaver (2001), and Bhuiyan \& Alam (2005), who found that the quality system had to be internally audited on a regular basis to identify remaining gaps. Basir et al. (2013) and Hassan (2015) also agreed that certified MS 1900 organisations conducted regular and timely internal audits to implement the MS 1900 effectively.

\section{External Audits}

External audits meant engaging an accredited registration/ certified body to perform an audit and certify that the quality management system complied with the requirements of quality management system requirements (Fuentes et al., 2000 and Seaver, 2001). The research indicated that the accreditation body (SIRIM) sent a notification to DHWZ as the certification renewal date approached, that they would conduct an external audit. They had informed the department of the auditor's name, and the date and time of the compliance audit. The accreditation body (SIRIM) was normally represented by two officers, the auditing would take about three days, and the external audit was carried out once a year. The auditor would have looked at the internal audit report of DHWZ prior to commencing the external audit. If there had been any issue of non-compliance found in the internal audit, the external auditor would ask if these had been improved. Officers who handled and implemented work procedures would subsequently be audited.

Documentation had been emphasized at the department to demonstrate the implementation of programs and activities at DHWZ. Workers who implemented the work procedures were also interviewed. SIRIM auditors presented a final report during the closing audit meeting and the report was to be handed to a management representative for further action. The research disclosed that external audits had been implemented regularly at DHWZ prior to MS 1900 certification. Hassan (2015) also found that external audits had been carried out in organisations that were successful in acquiring MS 1900 certifications. Basir \& Azmi (2011) argued that audit works acted as a control mechanism to monitor products and services delivered and ensure that they were by certified MS 1900 organisations, complying with the the Shari'ah requirements.

\section{Benefits of Implementing the MS 1900}

The research indicated that DHWZ gained three benefits from the implementation of MS 1900, and these included achieving the client's charter, being listed as an outstanding religious department and having systematic job management.

\section{Achieving the Client's Charter}

Figure 2 shows achievement of the Client's Charter by DHWZ from January to October 2012. One of the benefits of the MS 1900 was being able to meet some principles of the DHWZ Client's Charter. From the ten points in the Client's Charter, five two-way interactions with customers and stakeholders related to the Charter, such as managing complaints, advice, advocacy and dissemination of information on the DHWZ website, managed to achieve the set target. Two charters related to DHWZ's core implementation, which were waqf, mal, zakah and Muslim pilgrimage, as well as publications achieved $60 \%$ of the set target. Meanwhile, the other issues of financial management and administration successfully obtained a percentage of $50 \%$ of the set target. This indicated that the code of ethics, moral values in Islam and the sharing of knowledge had been successfully delivered and accepted by DHWZ staff. These findings closely resembled those of Magd et al. (2003), Williams (2004) and Munechika et al. (2014) who discovered that quality management system implementation 
increased customer's satisfaction in certified quality system organizations. The findings also supported those of Basir et al. (2013) that MS 1900 implementation brought a positive effect, such as meeting the needs of customers.

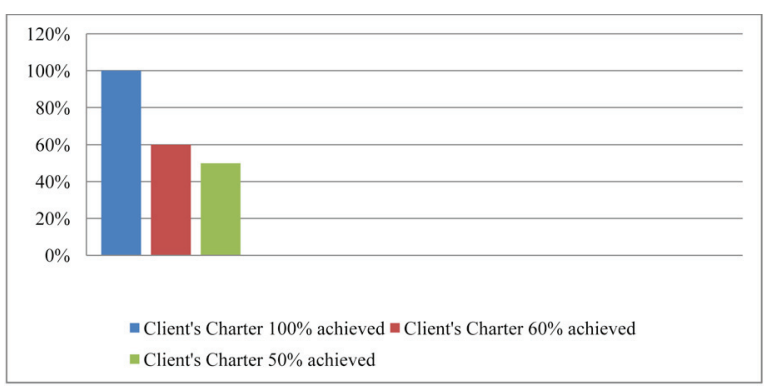

Figure 2: Customers Charter Achievement at the Department of Hajj, Waqf and Zakah (January-October 2012)

Source: DHWZ website (2012)

\section{Outstanding Religious Department}

A further benefit of the MS 1900 certification is that, it has made DHWZ an advanced religious department at the national level. DHWZ was successful in attaining the MS 1900 certification and this enhanced the reputation and image of the department. In addition, it had also developed a strong discipline among its workforce in delivering services. Based on the researcher's observations, DHWZ staff served their customers earnestly. These findings supported the argument by Magd \& Curry (2003) that organisations that were certified with quality management system experienced a better public image. The findings were also relevant with Elg et al. (2011) that quality management systems were often viewed as tools for improving company's image, and consistent with Hassan (2015) who found that MS 1900 implementation helped improve the organisational image of Malaysian private institutions of higher education.

\section{Systematic Job Management}

Other benefits derived from the implementation of MS 1900 were that they were able to be a catalyst and advocated for the work being carried out to be orderly, organized, systematic, complete and updated from time to time. This system was also said to have simplified management activities at DHWZ. For example, when there was a need to conduct a program, the workflow was more organized and staff felt capable of implementing the program. Issues such as business applications and approvals could be managed properly because of the availability of records, compared to when there were no quality records previously.

DHWZ's employees could also directly understand the real work that was done by other divisions in the department because they could always refer to the work procedures that were in place. Therefore, if any staff or officer was on leave, someone else could take over the duties of that person. This had ensured that the task could be carried out smoothly. It also guaranteed work quality and productivity of employees at DHWZ. These findings were supported by Buttle (1997) and Psomas et al. (2011) who found that the management efficiency and quality improvement were two benefits that emerged from the implementation of quality management systems. The findings also concurred with Basir \& Azmi (2011) who argued that the implementation of the MS 1900 helped organisations improve their management systems.

\section{Conclusions}

In conclusion, the implementation of the MS 1900 in DHWZ is at a challenging phase as the quality management system is being fully integrated with ISO 9001 (2008) to suit the needs of the Shari'ah. It had caused confusion among officers and employees at first. However, the MS1900 was the first such standard in the world and DHWZ was in the first group of 15 organizations to pioneer its implementation at the national level. The MS 1900 certification was eventually awarded to DHWZ as a result of the commitment shown by all parties.

The research findings identified six main activities that were undertaken under the 
MS 1900 implementation at DHWZ, namely gap analysis, preparation of the relevant documentation, creating quality groups, implementing work procedures, and carrying out internal and external audits. The research findings also identified three benefits accrued from the implementation of the MS 1900, which were achieving the client's charter, being listed as an outstanding religious department and systematic job management. It is apparent that MS 1900 was implemented effectively and it has proven beneficial to DHWZ.

Many past studies on quality initiatives employed the quantitative method, whereas this study used a qualitative method so that details of the phenomenon of quality system implementation could be explored. This study adds to the knowledge of the emergence and development of the Islamic quality management system MS 1900. It also contributes particular insights into the MS 1900 implementation within Islamic institutions in Malaysia. The findings from this paper can be used by managers in government or private institutions as a guideline in their endeavor to implement the MS 1900 effectively.

This study involved a case study but future studies could include several case studies to draw generalizations from them. It also focused on the MS 1900 implementation at Islamic institutions; future research could cover other sectors implementing the ISO 9000 such as in the education and medical sectors. While this study only looked at the scope of the MS 1900 implementation activities and its benefits, future research could explore other scopes of equal importance, such as the study of the impact of organizational culture or soft factors on the MS 1900 implementation.

\section{References}

Laman Utama Standard Malaysia (n.d)Retrieved February 25th 2013. Retrieved from http://www. standardsmalaysia.gov.my/
Abderrahman, H. (2012). "Islamic Perspectives on Training and Professional Development," Journal of Management Development 31, no.10, 1035-1045.

Al-Qaradhawi, Y. (2008). al-Siyāsah al-Syarī'ah fī Ḍhau'ī Nușūṣ al-Syarī'ah wa Maqāșidiha. Kaherah: Maktabah Wahbah.

Basir, S.A., \& Azmi, I. A. G. (2011). Malaysian Islamic Quality Management System MS 1900 from an Islamic perspective: an Implementation Model. Journal of Shari' ah, University Malaya Press, vol. 19(2), pp. 85-106.

Basir, S.A., Azmi, I.A.G., \& Kamri, N.A. (2013). Sistem Pengurusan Kualiti Islam MS 1900 sebagai Program Inovasi Pentadbiran Awam: Kajian Kes di Pusat Zakat Melaka (PZM). Prosiding Seminar Inovasi Pentadbiran Awam Malaysia, anjuran USM \& INTAN, 3-4 Oktober, 2013.

Bhuiyan, N., \& Alam. N. (2005). A Case Study of Quality System Implementation in a Small Manufacturing Firm. International Journal of Productivity Management, vol. 54(3), pp.172186.

Brown, V., \& Clarke, V. (2006). Using thematic analysis in psychology. Qualitative Research in Psychology. vol. 32(2), pp. 77-101.

Buttle, F. (1997). ISO 9000: Marketing Motivations and Benefits. International Journal of Quality and Reliability Management, vol. 14(9), pp.936-947.

Elg, M., Gremyr, I., Hellstrom, A., \& Witell, L. (2011). The role of quality managers in contemporary organisations. Total Quality Management \& Business Excellence, 22(8): 795-806.

Fadhilah, Y. (2011). "Teks ucapan, Majlis Penyampaian Sijil dan Seminar MS 1900:2005, Institut Kefahaman Islam Malaysia. 
Fuentes, C. M., Benavent, F. B., Moreno, M. A. E., Cruz, T. G., \& Val, M. P. (2000). Analysis of the Implementation of ISO 9000 Quality Assurance Systems. Work Study, vol. 49(6), pp.229-241.

Hassan, A. M., Ab. Mu'min, A. G. \& Siti Arni, B. (2014). Sistem Pengurusan Kualiti Menurut Perspektif Islam MS 1900 di Institusi Pengajian Tinggi Malaysia: Suatu Cabaran Masa Kini. Global Journal of Thaqafah (GJAT), 4(2):99113.

Hassan, A. M. (2015). Kajian Kes Perlaksanaan MS 1900 Sistem Pengurusan Kualiti Menurut Perspektif Islam di Institusi Pengajian Tinggi Malaysia. Unpublished Ph.D. thesis, University of Malaya.

Idris, A. (2009). Penyelidikan Ilmiah Amalan Dalam Pengajian Islam. Shah Alam: Kamil \& Shakir Sdn. Bhd.

Ilhaamie, A. G. A., Sharifah Hayaati, S. I., \& Siti Arni, B. (2013). Kualiti Perkhidmatan Awam Menurut Islam. Kuala Lumpur: University Malaya Press.

Magd, H. \& Curry, A. (2003). ISO 9000 and TQM. The TQM Magazine, vol. 15(4), pp.244256.

Magd, H., Kadasah, N. \& Curry, A. (2003). ISO 9000 Implementation. Managerial Auditing Journal, vol. 18(4), pp.313-322.

Malaysian Certified (2014), Malaysian Certified website. (Electronic Version). Retrieved on 11 March 2014. Retrieved from http://www. malaysiancertified.com.my. .

Mohd Affandi, H. (1992). The Tawhidic Approach in Management and Public Administration; Concepts, Principles and an Alternative Model. Kuala Lumpur: INTAN.

Motwani, J., Kumar, A., \& Cheng, C. H. (1996). A Roadmap to Implementing ISO 9000.
International Journal of Quality and Reliability Management, vol. 13(1), pp.72-83

Muhamad Abu, Z. (2009). Tārīkh al-Maẓahib al-Islạmiah. Kaherah: Dar al-Fikr al-Arabi.

Mukhtar, A. (1996). "Historical Developments of Quality and Productivity Management: Japan vs the West," in Quality Management Islamic Perspectives, ed. Abdul Hasan M.Sadeq and A.Khaliq Ahmad, Kuala Lumpur: Leeds Publication, 55.

Munechika, M., Sano, M., Jin, H., \& Kajihara, C. (2014). Quality management system for health care and its effectiveness. Total Quality Managament. Vol. 25, no. 8, pp. 889-896.

Psomas, E.L., Fotopoulos, C.V., \& Kafetzopolulos, D. P. (2011). Core process management practices, quality tools and quality improvement in ISO 9001 certified manufacturing companies. Business Process Management Journal. Vol 17, no. 3, pp. 437-460.

Richard C. R. (1995), Randall's Practical Guide to ISO 9000: Implementation Registration. Massachusetts: Addison-Wesley Publishing Company.

Saeed, M., Ahmed, Z. U. \& Mukhtar, S. M. (2001). International Marketing Ethics from an Islamic Perspective: A Value-Maximization Approach. Journal of Business Ethics 32, 127142.

Sany Sanury, Mohd., \& Mokhtar. (2011). Aplikasi Sistem Pengurusan Kualiti dari Perspektif Islam. Sintok. Universiti Utara Malaysia Press.

Seaver, M. (2001). Implementing ISO 9000:2000. England. Gower Publishing Company.

Siti Arni, B., \& Ilhaamie A. G. A. (2011). Malaysian Islamic Quality Management System MS 1900 from an Islamic perspective: an 
GJAT | DECEMBER 2016 | VOL 6 ISSUE 2 | 98

ISSN : 2232-0474 | E-ISSN : 2232-0482

www.gjat.my

implementation model, Sha'riah Journal, UM Press, 19 (2), pp. 85-106.

Standards and Industrial Research Institute of Malaysia, SIRIM, 2013.

Syed Arabi, I. (1993). Kaedah Penyelidikan Komunikasi dan Sains Sosial. Kuala Lumpur: Dewan Bahasa dan Pustaka.

Syed Azauddin, S.B. (2005). Alternative Quality Management Standards From Islamic Perspective (A Look at Their Rationale and Implementation). Kuala Lumpur: Utusan Publications \& Distributors Sdn. Bhd.

Wahbah Al-Zuhaily. (2006). Usul al-Fiqh alIslami. Damsyiq: Dar al-Fikr.

Williams, M. \& May, T. (1996). Introduction to the Philosophy of Social Research. (1st ed.,) UCL Press.

Yusof , I. (2004). Mengurus Secara Islam; Model dan Prinsip-prinsip Pengurusan Islam Bagi Individu dan Organisasi. Kuala Lumpur: A.S.Noorden. 